\title{
Groundwater Recharge and Hydrogeochemical Evolution in Leizhou Peninsula, China
}

\author{
Yintao Lu, ${ }^{1,2}$ Changyuan Tang, ${ }^{3}$ Jianyao Chen, ${ }^{4}$ and Junhong Chen ${ }^{5}$ \\ ${ }^{1}$ School of Civil Engineering, Beijing Jiaotong University, Beijing 100044, China \\ ${ }^{2}$ Beijing Key Laboratory of Aqueous Typical Pollutants Control and Water Quality Safeguard, Beijing 10044, China \\ ${ }^{3}$ Faculty of Horticulture, Chiba University, Chiba 271-8510, Japan \\ ${ }^{4}$ Geography and Planning School, Sun Yat-sen University, Guangzhou 510275, China \\ ${ }^{5}$ Guangzhou Institute of Geography, Guangzhou 510070, China \\ Correspondence should be addressed to Yintao Lu; luytaocn@163.com
}

Received 3 May 2015; Revised 24 June 2015; Accepted 28 June 2015

Academic Editor: Franco Tassi

Copyright (C) 2015 Yintao Lu et al. This is an open access article distributed under the Creative Commons Attribution License, which permits unrestricted use, distribution, and reproduction in any medium, provided the original work is properly cited.

\begin{abstract}
An analysis of the stable isotopes and the major ions in the surface water and groundwater in the Leizhou Peninsula was performed to identify the sources and recharge mechanisms of the groundwater. In this study, 70 water samples were collected from rivers, a lake, and pumping wells. The surface water was considered to have a lower salinity than the groundwater in the region of study. The regression equations for $\delta \mathrm{D}$ and $\delta^{18} \mathrm{O}$ for the surface water and the groundwater are similar to those for precipitation, indicating meteoric origins. The $\delta \mathrm{D}$ and $\delta^{18} \mathrm{O}$ levels in the groundwater ranged from $-60 \%$; to $-25 \%$; and $-8.6 \%$; to $-2.5 \%$, respectively, and were lower than the stable isotope levels from the winter and spring precipitation. The groundwater in the southern area was classified as the $\mathrm{Ca}^{2+}-\mathrm{Mg}^{2+}-\mathrm{HCO}_{3}^{-}$-type, whereas the groundwater in the northern area included three types $\left(\mathrm{Na}^{+}-\mathrm{Cl}^{-}\right.$-type, $\mathrm{Ca}^{2+}-\mathrm{Mg}^{2+}-\mathrm{HCO}_{3}{ }^{-}$-type, and $\mathrm{Ca}^{2+}-\mathrm{Mg}^{2+}-\mathrm{Cl}^{-}$-type), indicating rapid and frequent water-rock exchange in the region. A reasonable conclusion is that the groundwater chemistry is dominated by rock weathering and rainwater of local origin, which are influenced by seawater carried by the Asian monsoon.
\end{abstract}

\section{Introduction}

The Leizhou Peninsula is located in the southwestern region of Guangdong province of China. Unconsolidated alluvial and lacustrine sediments and Neogene and Quaternary volcanic rocks overlie the basement rocks in this area [1]. The hydrodynamic evolution of groundwater is closely related to Quaternary volcanic activity, and groundwater geochemistry processes and the evolution of water chemistry exhibit unique characteristics. Consequently, studying stable isotope and geochemical techniques can significantly improve our understanding of groundwater hydrodynamical processes and chemical evolution. In the volcanic rock region of the island, rainwater quickly infiltrates into the ground because of its hydrogeological characteristics. Thus, it can be assumed that no significant evapotranspiration of rainwater occurs before or after infiltration [2]. Although volcanic rocks occupy a small fraction of the earth's surface, the hydrogeology of aquifers that are composed of volcanic deposits is important in the numerous islands and continental areas in which these materials are prominent [3]. Additionally, studies of the geochemistry of aqueous fluids in volcanic regions have been conducted in rivers around the world to understand the weathering of basaltic rocks and have provided information regarding geochemical cycles [4-6]. Most of the ions that are released into the water result from water-rock interactions in basaltic aquifers [7].

Stable isotopes and geochemical techniques are important for determining the origins of groundwater in aquifers [8], water cycling processes, and the rock-water interactions [9] and dominant geochemical reactions that control the surface water and groundwater quality. Stable isotope and chemical techniques have been used in groundwater studies of basaltic aquifers worldwide, for example, the Vesuvius Volcano in Italy [10-12], the Central Indian Peninsula [13], Kos Island [14], and Chios Island of Greece [15]. Chemical 
processes may provide evidence of groundwater flow. The major ions in natural waters (e.g., $\mathrm{K}^{+}, \mathrm{Na}^{+}, \mathrm{Ca}^{2+}, \mathrm{Mg}^{2+}, \mathrm{Cl}^{-}$, $\mathrm{SO}_{4}{ }^{2-}$, and $\mathrm{HCO}_{3}{ }^{-}$) have been widely studied to understand the geology of catchments, material loading into lakes and oceans, and local processes that affect water chemistry, such as rock weathering, evaporation/crystallization, and atmospheric precipitation [16].

The Leizhou Peninsula is an ideal site for investigating volcanic hydrogeological environments [17]. A recent study indicated that groundwater contains low total dissolved solids (TDS) (ranging from 40 to $550 \mathrm{mg} / \mathrm{L}$ ), is weakly acidic, and has a low $\mathrm{pH}$ between 4 and 7 [18]. Groundwater exploitation in this area began in the 1950s and has increased each year since 1980 due to industrial, agricultural, and municipal use. Various negative effects of groundwater overexploitation, such as decreasing groundwater levels, land subsidence, and seawater intrusion [18], have become serious threats to volcanic hydrogeology and water quality.

This study was conducted in the Leizhou Peninsula with the following objectives: (1) to define the sources and origins of groundwater and surface water using stable isotope $\left({ }^{18} \mathrm{O}\right.$ and D) measurements; (2) to explain groundwater recharge and discharge by measuring the chemical compositions of groundwater; and (3) to analyze water-rock interactions based on hydrogeology and chemistry. The results of this study can be used to improve our understanding of hydrogeochemical processes and enable the protection and sustainable use of water resources.

\section{Materials and Methods}

2.1. Site Description. The Leizhou Peninsula is located at the northern boundary of the Tropic of Capricorn in South China (Figure 1). The precipitation in this region is strongly influenced by the East Asian summer monsoon and, to a lesser extent, by the Indian summer monsoon [17]. This area, along with the entire South China Sea, provides the moisture supply for the summer monsoon rainfall throughout the eastern part of China from June to August and has a rich average annual rainfall of $1400 \mathrm{~mm}$, with approximately $75 \%$ of the precipitation falling during this rainy season. From October to March of the following year, the northwestern winter monsoon prevails, which brings cold and dry continental air from the Siberian and Mongolian highlands that reduces the amount of precipitation that occurs in the Leizhou Peninsula. A significant water shortage occurs due to high evapotranspiration during the dry season. The mean annual temperature is $22-23^{\circ} \mathrm{C}$. The Leizhou Peninsula has a relatively flat volcanic topography and is located in the Tianyang basin in the south, which erupted between the midMiocene and Quaternary period. The volcanic rocks in the peninsula are mainly basalts and constitute more than $40 \%$ of the total surface area of the study region (Figure 1). The basement rocks primarily consist of sandy shale, clay rocks, and granite. The volcanic basalt terrace is primarily at an altitude of 10-50 m, although certain volcanic cones reach altitudes of 100-260 m. However, Tianyang basalt primarily contains peridotite xenoliths and a few smaller clinopyroxene megacrysts [1].
The surface hydrogeological map (Figure 2(a)) primarily shows two types of aquifers: a loose rock porous aquifer in the north and a volcanic fissured aquifer in the south. These types of aquifers are accompanied by small amounts of coastal sandy porous aquifers in the surrounding coast. The geologic cross section shown in Figure 2(b) indicates that the thickness of the phreatic aquifer increases from 5 to $15 \mathrm{~m}$ from north to south. The aquifer is primarily composed of gravel and sand, and the aquitard consists of weathered basalt. Within $800 \mathrm{~m}$ of the surface, 3 to 25 aquifers exist in the plains of the northern area and 2 to 3 aquifers exist in the highlands of the southern area. The basalt aquifer exhibits a higher hydraulic conductivity (average $234.3 \mathrm{~m} / \mathrm{d}$ ) and transmissivity (average $6904.3 \mathrm{~m}^{2} / \mathrm{d}$ ) [19]. In addition, infiltration coefficients range from $3 \%$ to $20 \%$ of the total rainfall in the basaltic materials [20].

Rich groundwater reserves are located in the Leizhou Peninsula, and the flow of groundwater in basaltic aquifers primarily occurs through open fractures and joints. Fossilized soils act as a local barrier to vertical flow. Therefore, perched aquifers have developed in areas containing thick and broad layers of these soils [7]. Highly developed fractures and vertical joints in the volcanic rocks result in a high vertical hydraulic conductivity, and rainfall infiltrates rapidly with only a slight surface runoff. Therefore, despite heavy rainfall during the summer, only a slight sustained stream flow occurs in the peninsular region. In addition, old basaltic lava flows with high permeabilities are widely distributed over the Leizhou Peninsula, producing good hydrological conditions for the groundwater [22].

2.2. Water Sampling and Chemical Analysis. Groundwater (shallow groundwater) and surface water samples were collected from the Leizhou Peninsula in June 2006 and used to analyze the groundwater source and groundwater flow system. Groundwater samples were collected from wells at depths of $10-30 \mathrm{~m}$. The samples were collected as evenly as possible across the study area. Thus, some groundwater samples fell into the overall hydrogeological unit. Groundwater table contouring is similar to topographic contouring (Figure 2(c), [21]), with the shallow groundwater discharge occurring from high to low topography. The electrical conductivity (EC), $\mathrm{pH}, \mathrm{TDS}$, and temperature were determined in the field at the time of sampling. All of the water samples were transported to the laboratory at Chiba University to analyze the major ion concentrations and stable isotopes $(\delta \mathrm{D}$ and $\left.\delta^{18} \mathrm{O}\right)$.

The concentrations of $\mathrm{K}^{+}, \mathrm{Na}^{+}, \mathrm{Ca}^{2+}, \mathrm{Mg}^{2+}, \mathrm{NH}_{4}{ }^{+}, \mathrm{Cl}^{-}$, $\mathrm{SO}_{4}{ }^{2-}$, and $\mathrm{NO}_{3}{ }^{-}$were analyzed using ion chromatography (HPLC, Shimazu LC-10A, Japan), and the $\mathrm{HCO}_{3}{ }^{-}$concentration was determined by titration [23]. The stable isotopes $\left({ }^{18} \mathrm{O}\right.$ and $\left.\mathrm{D}\right)$ were analyzed using a mass spectrometer (Finnigan MAT Delta S). The analytical precision for all cation and anion concentrations was $2 \%$. For the oxygen isotopic analysis, approximately $10 \mathrm{~mL}$ of each water sample was equilibrated with $\mathrm{CO}_{2}$ by shaking for 6 hours at $25^{\circ} \mathrm{C}$ [24]. For the hydrogen isotopic analysis, metallic zinc was used to produce hydrogen gas using the zinc reduction method [25]. The $\delta^{18} \mathrm{O}$ and $\delta \mathrm{D}$ levels were reported per 


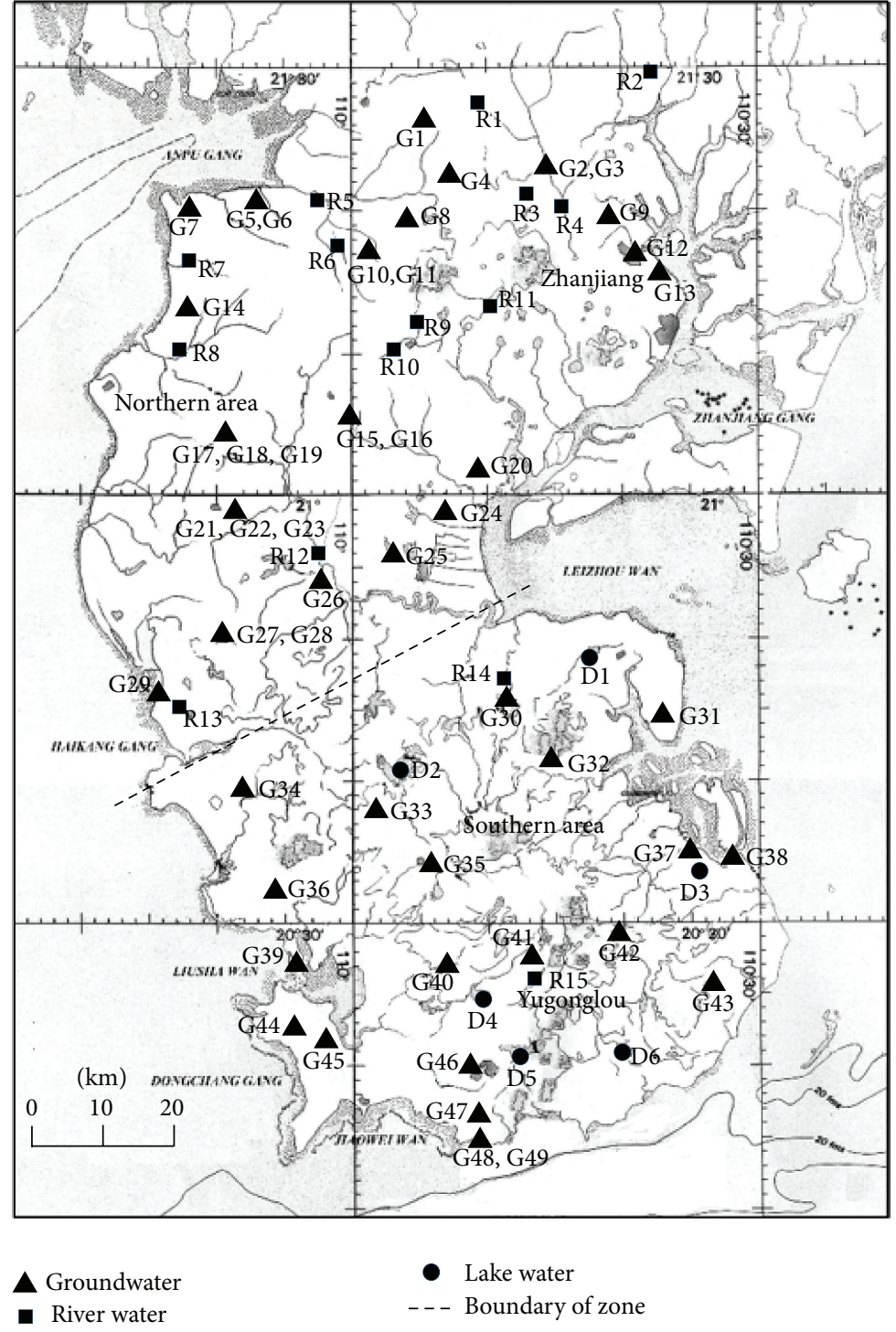

(a)

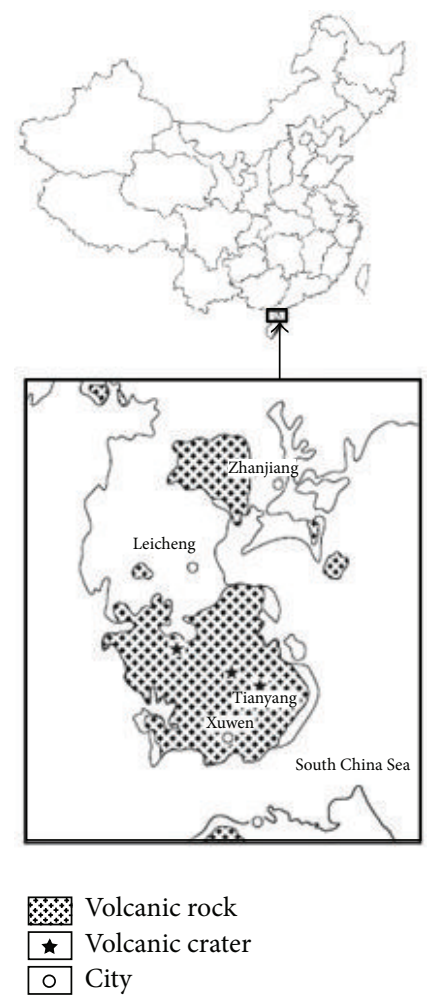

(b)

Figure 1: Map of Leizhou Peninsula showing (a) the sampling locations and (b) Tianyang crater. The map is subdivided into two areas: the northern area and the southern area.

mil (\%o) relative to the Vienna Standard Mean Ocean Water (VSMOW) standard. The analytical reproducibilities were $\pm 0.1 \%$ or for $\delta^{18} \mathrm{O}$ and $\pm 1 \%$ for $\delta \mathrm{D}$.

2.3. Statistical Analysis. The Piper diagram is a graphical representation of the water sample chemistry that is widely used to evaluate the hydrochemical evolution of surface water and groundwater [26]. Overall, there are 9 zones in the Piper diagram (Figure 3), each of which corresponds to a different water type. For example, the water samples collected in zone 9 indicate that the surface water and the groundwater were dominated by $\mathrm{SO}_{4}{ }^{2-}$. However, the water samples in zone 5 indicated waters dominated by $\mathrm{HCO}_{3}{ }^{-}$and $\mathrm{Ca}^{2+}+\mathrm{Mg}^{2+}$.

Gibbs diagrams (Figure 4) are widely used to establish the relationships between the water composition and the lithological characteristics of the aquifer [27]. Three distinct fields, including precipitation dominance, evaporation dominance, and rock weathering dominance, constitute the segments in the Gibbs diagram, which can be interpreted using a simple plot of the TDS versus the weight ratio of $\mathrm{Na}^{+} /\left(\mathrm{Na}^{+}+\right.$ $\left.\mathrm{Ca}^{2+}\right)$ or $\mathrm{Cl}^{-} /\left(\mathrm{Cl}^{-}+\mathrm{HCO}_{3}^{-}\right)$.

PHREEQC [28] can be used to analyze problems involving the speciation of environmental pollutants and to determine which solids could be precipitated based on the saturation index (SI; $[29,30])$. The SI of a mineral is obtained as follows:

$$
\mathrm{SI}=\log \frac{\mathrm{IAP}}{K_{\mathrm{sp}}},
$$

where IAP is the ion activity product of the dissociated chemical species in solution and $K_{\mathrm{sp}}$ is the equilibrium 


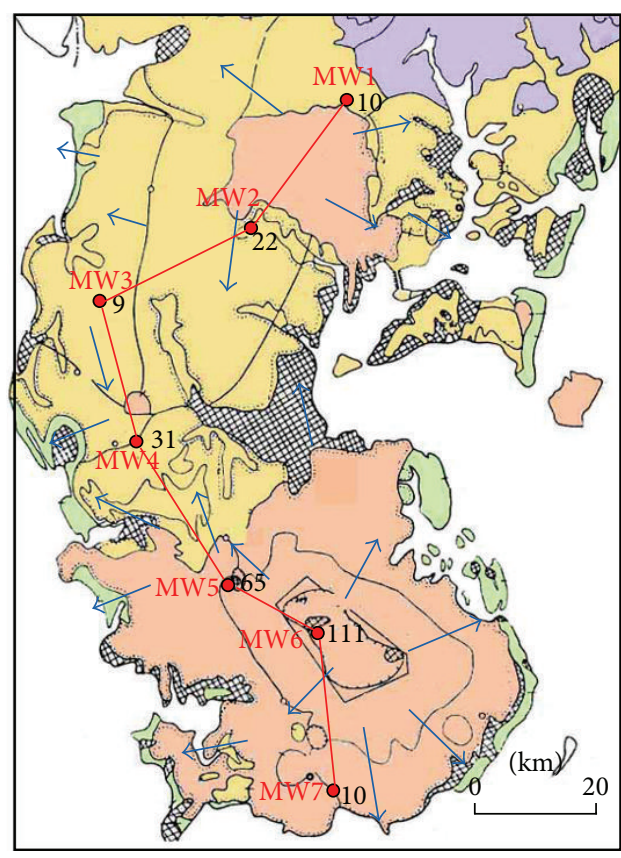

Loose rock porous aquifer Coastal sand porous aquifer Volcanic fissured aquifer Bedrock fissured aquifer
Aquiclude

$0_{10}$ Monitor well and elevation $\longrightarrow$ Groundwater flow direction

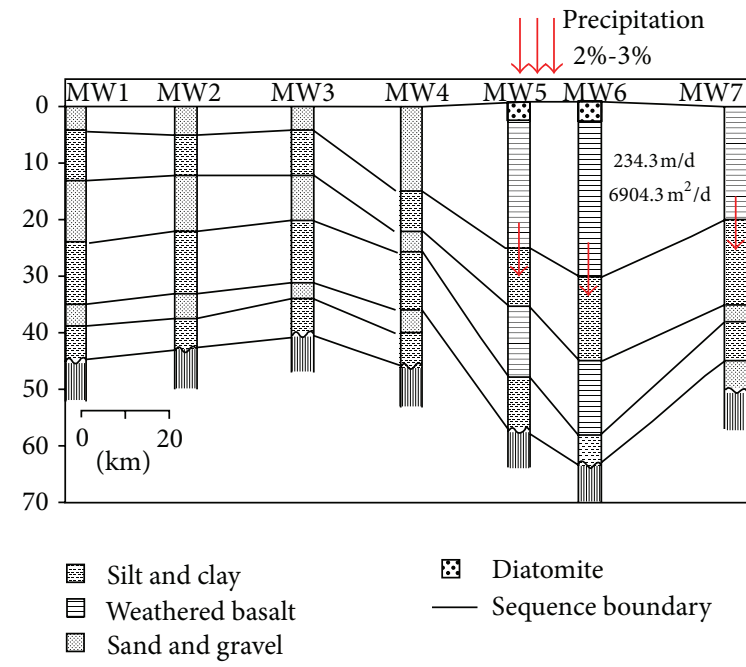

(a)

(b)

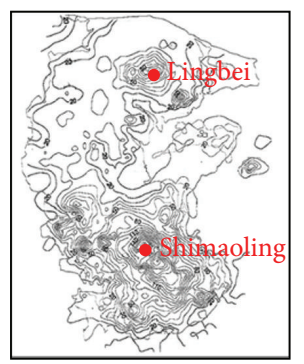

(c)

FIGURE 2: Hydrogeological map of the study region. (a) Aquifer distribution and groundwater flow direction. Two main aquifer types exist in this region, porous aquifers, including loose rock and coastal sand, and fissured aquifers, including volcanic rocks and bedrock. (b) Simplified cross section from MW1 to MW7 of (a) [19-21]. (c) An elevation map showing the two sites at higher elevations (Shimaoling and Lingbei).

solubility product for the respective mineral at the sample temperature. Negative and positive SI values represent the potential for dissolution and precipitation, respectively.

\section{Results and Discussion}

3.1. $\delta^{18} \mathrm{O} / \delta D$ Isotopes and Groundwater Origin. Water isotopic data can be used to determine the atmospheric moisture sources and meteorological and geographical factors that cause rain. The relationship between the $\delta \mathrm{D}$ and $\delta^{18} \mathrm{O}$ levels for the surface water and groundwater is shown in Figure 5. The stable isotope data of the groundwater varied from $-60 \%$ o to $-25 \%$ o for $\delta \mathrm{D}$ and from $-8.6 \%$ to $-2.5 \%$ o for $\delta^{18} \mathrm{O}$. The $\delta \mathrm{D}$ and $\delta^{18} \mathrm{O}$ levels for the surface water (the river water and the lake water) ranged from $-56 \%$ to $-28 \%$ and from $-6.2 \%$ to $-2.6 \%$, respectively. A local meteoric water line (LMWL) for Hong Kong was used to interpret the data in this study. The isotope composition of the precipitation was plotted along the LMWL using the following equation: $\delta \mathrm{D}=$ $8.1 \delta^{18} \mathrm{O}+11.4$ (which had a correlation coefficient, $R^{2}$, of 0.99 , using data from the International Atomic Energy Agency). The isotopic data for the groundwater were linearly fit using the regression equation $\delta \mathrm{D}=6.0 \delta^{18} \mathrm{O}-10.4\left(R^{2}=0.81\right)$, and the isotopic data from the surface water were linearly fit using the regression equation $\delta \mathrm{D}=5.4 \delta^{18} \mathrm{O}-15.5$ (with a correlation coefficient, $R^{2}$, of 0.95 ), which intersected the LMWL at $\delta \mathrm{D}=-70 \%$ and $\delta^{18} \mathrm{O}=10.0 \%$. This regression line can be interpreted as the local evaporation line (LEL) in the 


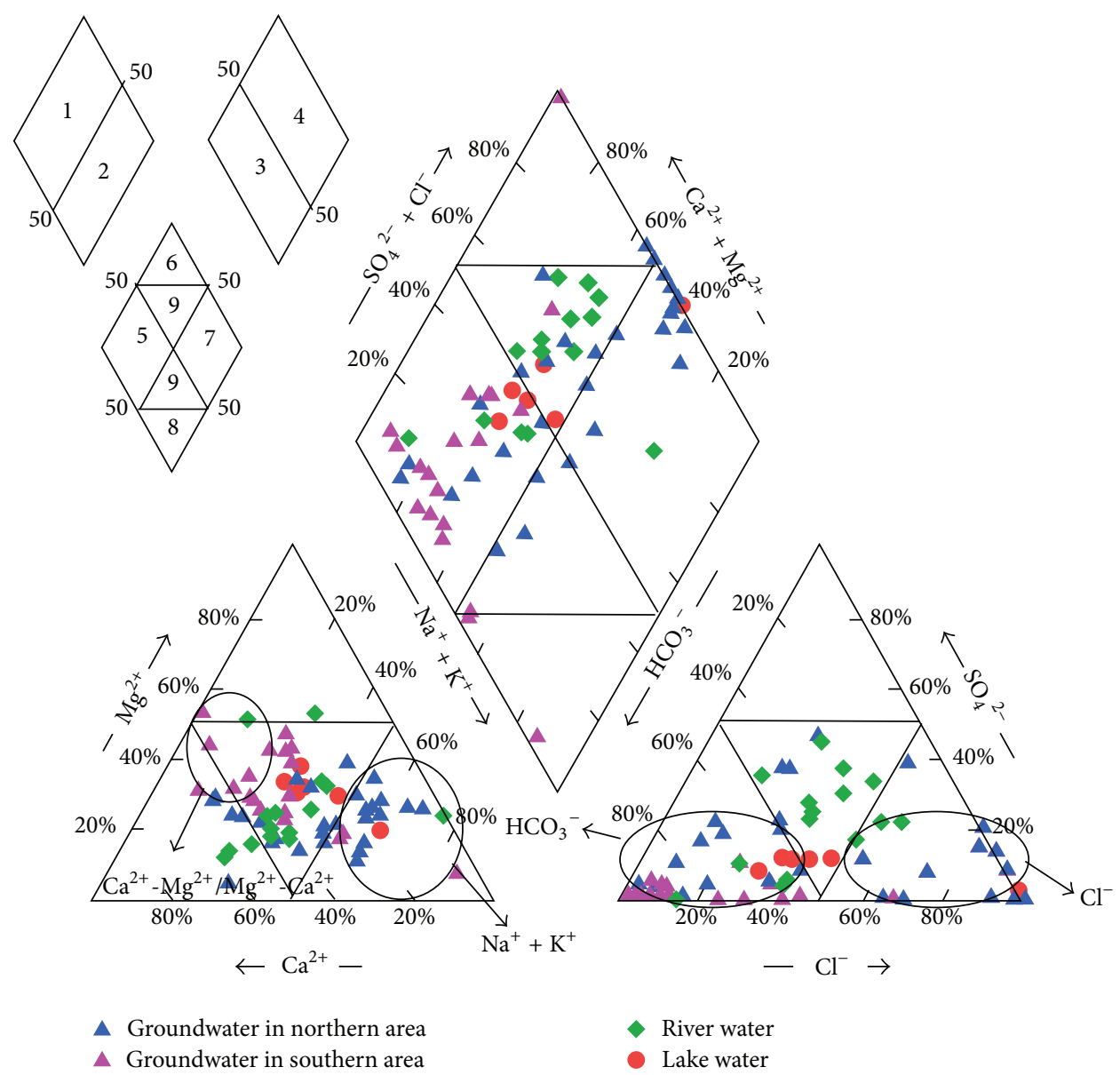

FIGURE 3: Piper diagrams for surface water and groundwater in the Leizhou Peninsula; water samples are classified as zone 1, which indicates that they are dominated by $\mathrm{SO}_{4}{ }^{2-}, \mathrm{Cl}^{-}, \mathrm{HCO}_{3}{ }^{-}$, and $\mathrm{Ca}^{2+}+\mathrm{Mg}^{2+}$.

study region. Additionally, Figure 5 shows that the isotopic composition of most of the groundwater (except for sampling sites numbers G32 and G37 in the region of study) lies within a narrow range, confirming that these groundwater samples had the same recharge source. Furthermore, the isotope compositions of the groundwater and surface water samples are primarily along the LMWL, which indicates that they are of meteoric origin.

The isotope composition in the precipitation was depleted by the monthly amount of precipitation (Figure 6). Shallow groundwater originates from precipitation; thus, the isotope composition of the groundwater was $\delta \mathrm{D}<-25 \%$ ond $\delta^{18} \mathrm{O}<$ $-2.5 \%$. The isotope composition of the monthly precipitation showed that only rainfall from June to September $(-5.93 \%$ < $\delta^{18} \mathrm{O}<-3.29 \%$ and $-29.9 \%$ o $<\delta^{18} \mathrm{O}<-50.3 \%$ ) recharged the groundwater. The climate in the Leizhou Peninsula is affected by air masses with different qualities in the summer and winter [26], which results in different $\delta \mathrm{D}$ and $\delta^{18} \mathrm{O}$ levels during these seasons [31]. However, during the summer, higher temperatures and an abundance of surface water bodies may serve as moisture sources for precipitation with local origins [32]. In addition, surface water samples are considered isotopically heavier than groundwater because of evaporation [33]. This consideration can be used to explain why the groundwater and surface water samples lay below the LMWL (Figure 5); that is, these samples were primarily affected by enhanced moisture loss [34]. The $\delta \mathrm{D}$ and $\delta^{18} \mathrm{O}$ levels of the groundwater were most similar to the stable isotope levels for precipitation during the summer, which implies that the groundwater was affected by the rainfall from the local air mass. The surface in the study region is covered by 2.5 to $3 \mathrm{~m}$ of thick, red soil underneath the basalt. Red soils have high hydraulic conductivities between $6.16 \times 10^{-7}$ and $1.11 \times 10^{-4} \mathrm{~m} / \mathrm{s}$. In addition, cracks are often found on the soil surface when the top layer dries upon exposure to sunshine. Thus, it is very easy for rainwater to infiltrate the soil [22]. However, the volcanic basaltic aquifer had higher infiltration coefficients ( $3 \%$ to $20 \%$ of the total rainfall) [20]. These factors suggest that storm water rapidly infiltrates through open fractures and joints in the rocks to recharge the groundwater.

3.2. The Water Quality and Spatial Distribution of Groundwater Chemistry. The chemical composition of groundwater evolves during regional flows and can be generalized by considering the types of water that are typically found in different zones of groundwater flow systems [26, 35]. 


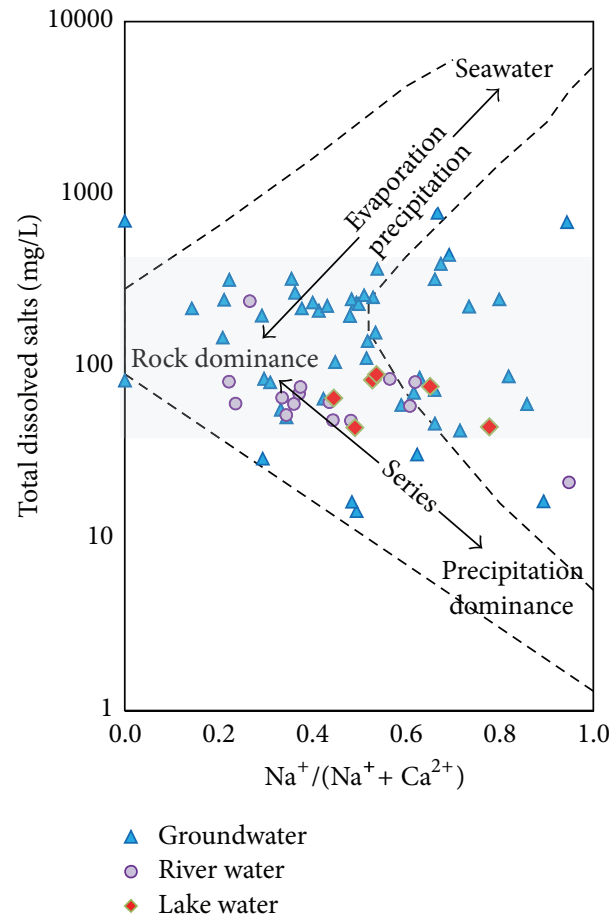

(a)

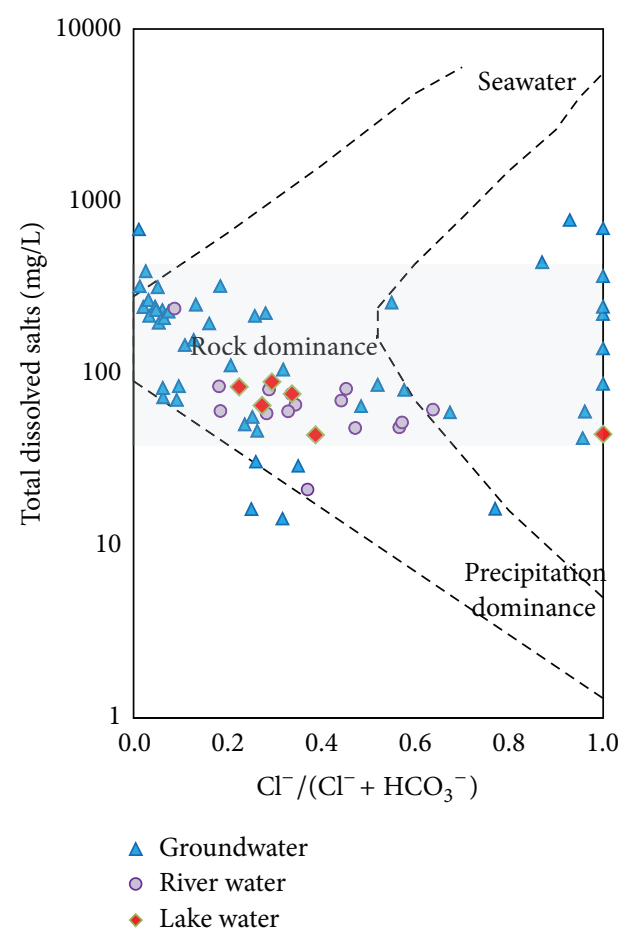

(b)

FIGURE 4: Gibbs diagram of surface water and groundwater samples in Leizhou Peninsula (the gray shaded area was introduced by Gibbs to indicate dominance of rock weathering).

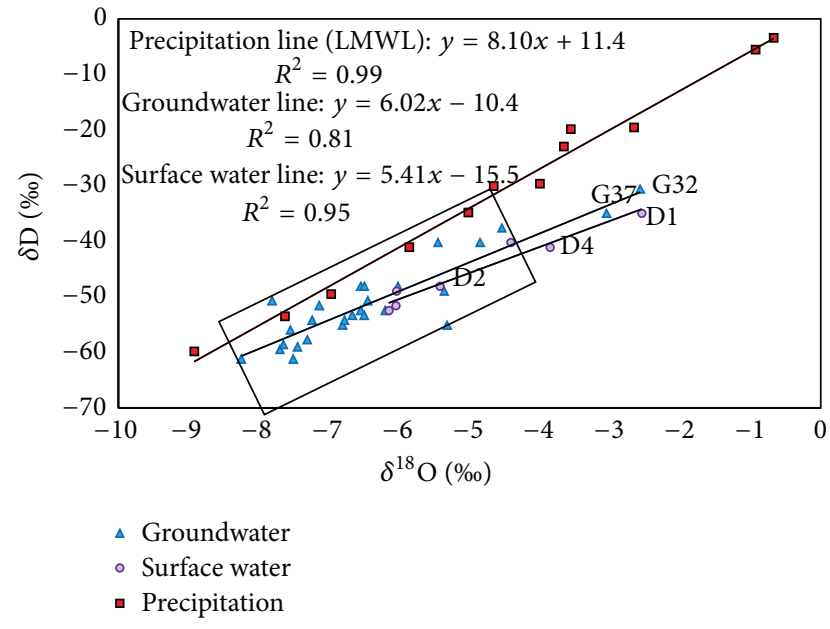

FIGURE 5: Relationships between $\delta \mathrm{D}$ and $\delta^{18} \mathrm{O}$ for precipitation, surface water, and groundwater in Leizhou Peninsula. The isotope levels in groundwater (except for sampling sites numbers G32 and G37 in the study region) lie within a narrow range.

The major ionic data for the water samples are shown in Supplementary Table 1 in Supplementary Material available online at http://dx.doi.org/10.1155/2015/427579. The TDS of the groundwater ranged from 14 (sampling site number G22) to $776 \mathrm{mg} / \mathrm{L}$ (sampling site number G18), and the EC values of the groundwater ranged from $22 \mu \mathrm{S} / \mathrm{cm}$ (sampling site

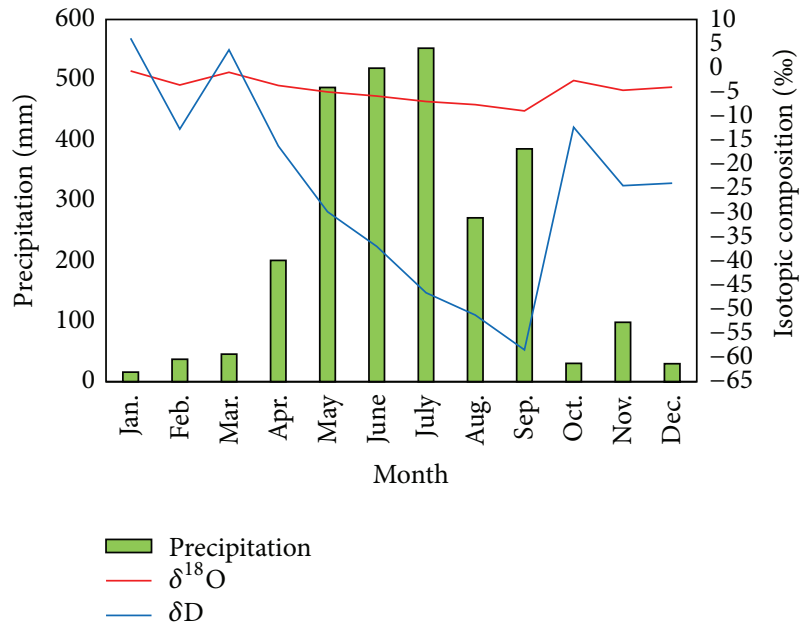

FIgURE 6: Monthly precipitation distribution and $\delta^{18} \mathrm{O}$ and $\delta \mathrm{D}$ levels for rainfall in Hong Kong in 2006 (data taken from International Atomic Energy Agency (IAEA) and its home page, https://www.iaea.org/).

number G22) to $1320 \mu \mathrm{S} / \mathrm{cm}$ (sampling site number G49). The surface water was characterized by lower ionic concentrations than the groundwater. The cation concentrations in the surface water decreased as follows: $\mathrm{Ca}^{2+}>\mathrm{Na}^{+}>\mathrm{Mg}^{2+}>\mathrm{K}^{+}$, with mean concentrations of $7.28,5.72,3.66$, and $3.36 \mathrm{mg} / \mathrm{L}$, respectively. The anion concentrations decreased as follows: 
$\mathrm{HCO}_{3}{ }^{-}>\mathrm{Cl}^{-}>\mathrm{SO}_{4}{ }^{2-}>\mathrm{NO}_{3}{ }^{-}$, with mean concentrations of $29.2,12.1,7.03$, and $4.53 \mathrm{mg} / \mathrm{L}$, respectively. Compared with the surface water samples, the order in which the cation concentrations in the groundwater decreased was different $\left(\mathrm{Na}^{+}>\mathrm{Ca}^{2+}>\mathrm{Mg}^{2+}>\mathrm{K}^{+}\right)$, and the cation concentrations were higher $(19.4,17.2,7.85$, and $5.68 \mathrm{mg} / \mathrm{L}$, resp.). The anion concentrations in the groundwater decreased in the following order: $\mathrm{HCO}_{3}{ }^{-}>\mathrm{Cl}^{-}>\mathrm{NO}_{3}{ }^{-}>\mathrm{SO}_{4}{ }^{2-}$, with mean concentrations of 57.2, 10.8, 3.37, and $3.35 \mathrm{mg} / \mathrm{L}$, respectively. Most of the surface water and groundwater had low salinities. The $\mathrm{NO}_{3}{ }^{-}$concentrations in the surface water were below the water quality standards for drinking water sources in China $\left(\mathrm{N}_{-} \mathrm{NO}_{3}{ }^{-}, 10 \mathrm{mg} / \mathrm{L}\right)$, but these concentrations were greater than the standards for certain groundwater samples (sampling sites numbers G3, G8, G12, G14, G18, G28, G42, and $\mathrm{G} 49$ ). $\mathrm{NO}_{3}{ }^{-}$is the most common water contaminant, and $\mathrm{NO}_{3}{ }^{-}$pollution is increasing because the number of anthropogenic sources is increasing. In recent years, the agricultural land area in the Leizhou Peninsula has increased by approximately 2,000,000 acres. In addition, copious amounts of nitrogenous fertilizer and phosphate fertilizers have been used, which have increased the groundwater $\mathrm{NO}_{3}{ }^{-}$concentrations [36].

The major ion compositions varied in the groundwater samples. However, these samples were generally $\mathrm{Ca}^{2+}+$ $\mathrm{Mg}^{2+}$-rich with no dominant type of anion (Figure 3). The triangular diagram shows that the groundwater chemistry was mainly characterized by three groups in the northern area. The first group was $\mathrm{Na}^{+}-\mathrm{K}^{+}-\mathrm{Cl}^{-}$-type groundwater, in which $\mathrm{Na}^{+}+\mathrm{K}^{+}$accounted for more than $70 \%$ of the total anions; the second group was $\mathrm{Ca}^{2+}-\mathrm{Mg}^{2+}-\mathrm{HCO}_{3}{ }^{-}$-type groundwater; and the third group was $\mathrm{Ca}^{2+}-\mathrm{Mg}^{2+}-\mathrm{Cl}^{-}$-type groundwater, in which $\mathrm{Ca}^{2+}$ and $\mathrm{Mg}^{2+}$ accounted for $30-$ $60 \%$ and $20-45 \%$ of the total cations, respectively. However, the groundwater in the southern area could be classified as $\mathrm{Ca}^{2+}-\mathrm{Mg}^{2+}-\mathrm{HCO}_{3}{ }^{-}$-type, which accounted for $74 \%$ of the total anions and cations. In addition, the $\mathrm{Na}^{+}-\mathrm{Cl}^{-}$-type and $\mathrm{Na}^{+}-\mathrm{HCO}_{3}{ }^{-}$-type groundwater accounted for $72 \%$ of the groundwater in the northern area and $28 \%$ of the groundwater in the southern area (Figure 7), which indicated that the chemical characteristics were different between the northern area and southern area.

In addition, the water was mainly characterized as $\mathrm{Ca}^{2+}$ $\mathrm{HCO}_{3}{ }^{-}$-type in the inland areas and as $\mathrm{Na}^{+}-\mathrm{Cl}^{-}$-type along the west coast (Figure 7). Hills are located in the middle of the southern area, the tallest of which is located in Shimaoling with an elevation of $259 \mathrm{~m}$. Two taller hills are located northeast of the northern area, and the highest point, with an elevation of $120 \mathrm{~m}$, is located in Beiling (Figure 2(c)). The shallow groundwater could significantly affect the direction of groundwater flow. Thus, the groundwater flows from a higher topography to a lower topography (see Figure 2(a); [21]). Supplementary Table 1 and Figure 1 show that the groundwater had a lower TDS $(<150 \mathrm{mg} / \mathrm{L})$ in the inland areas and a higher TDS $(>300 \mathrm{mg} / \mathrm{L})$ along the coast. Farid et al. suggested that the leaching of salts during waterrock interactions affects groundwater chemistry, along with evaporation losses during groundwater flow processes [37].
In addition, seawater intrusion increases the TDS contents in the coastal area [38]. Therefore, increases in the TDS contents along the direction of groundwater flow from inland areas to the coast likely resulted from the dissolution of minerals, evaporation, and seawater intrusion.

However, the frequency of occurrence and the magnitude of the natural processes in a region vary with time, and their influences are reflected in groundwater hydrochemistry as wide temporal fluctuations [39]. The clearest seasonal variations in groundwater composition were detected in many studies [40-42], with low concentrations during the wet season and high concentrations during the dry season. The groundwater samples in this study were collected from the Leizhou Peninsula in June 2006, which is the wet season. Thus, the chemical composition can represent the groundwater chemistry during the wet season. The concentration was lower than that during the dry season.

3.3. Mechanisms Controlling Natural Water Chemistry. A Gibbs diagram of the surface water and groundwater samples in Leizhou Peninsula is shown in Figure 4. Most of the surface water and groundwater samples were obtained in areas that were dominated by rock-water interactions where the ratios of $\mathrm{Na}^{+} /\left(\mathrm{Na}^{+}+\mathrm{Ca}^{2+}\right)$ or $\mathrm{Cl}^{-} /\left(\mathrm{Cl}^{-}+\mathrm{HCO}_{3}^{-}\right)$were less than 0.5 . Samples with $\mathrm{Na}^{+} /\left(\mathrm{Na}^{+}+\mathrm{Ca}^{2+}\right)$ or $\mathrm{Cl}^{-} /\left(\mathrm{Cl}^{-}+\mathrm{HCO}_{3}{ }^{-}\right)$ratios greater than 0.5 and TDS levels between 16 and $776 \mathrm{mg} / \mathrm{L}$ showed that the groundwater chemistry was controlled by not only rock weathering and/or atmospheric precipitation but also the saline water mixing or evaporation. In addition, Figure 8 shows that most of the water samples were slightly below saturation with respect to dolomite $\left(\mathrm{CaCO}_{3}\right)$ and calcite $\left(\mathrm{Ca}_{2} \mathrm{Mg}\left(\mathrm{CO}_{3}\right)_{2}\right)$.

The Tianyang volcanic rocks are composed of alkaliolivine basalt, which mainly consists of olivine, pyroxene, and plagioclase [43]. In the presence of slightly acidic rainwater, the original silicate minerals are quickly and incongruently dissolved $\left(\mathrm{Ca}>\mathrm{Na}>\mathrm{Mg}>\mathrm{K}>\mathrm{SiO}_{2}\right.$ ) [44]. The volcanic basalt of Leizhou Peninsula contains large amounts of $\mathrm{Si}, \mathrm{Fe}, \mathrm{Ai}$, $\mathrm{Ca}, \mathrm{Mg}$, and $\mathrm{Na}$ [45]. The rock-water interactions in basaltic aquifers $\left(\mathrm{CO}_{2}-\mathrm{H}_{2} \mathrm{O}\right.$-basalt $)$ are schematically summarized in (2) and (3) [46]. The relevant chemical equations are as follows:

$$
\begin{aligned}
& \mathrm{CO}_{2}+\mathrm{H}_{2} \mathrm{O} \longrightarrow \mathrm{HCO}_{3}{ }^{-}+\mathrm{H}^{+} \\
& \mathrm{Na}_{x}(\mathrm{Ca}, \mathrm{Mg}, \mathrm{Fe})_{y} \mathrm{Si}_{3} \mathrm{AlO}_{8}+(x+2 y+3) \mathrm{H}^{+}+4 \mathrm{H}_{2} \mathrm{O} \\
& \longrightarrow x \mathrm{Na}^{+}+y(\mathrm{Ca}, \mathrm{Mg}, \mathrm{Fe})^{2+}+3 \mathrm{H}_{4} \mathrm{SiO}_{4}+\mathrm{Al}^{3+}
\end{aligned}
$$

Many studies have shown that these rock-water interaction equations are equal in basaltic aquifers using reactivepercolation experiments and field investigations [47-49]. Herrera and Custodio showed a high $\mathrm{HCO}_{3}{ }^{-}$content between 305 and $549 \mathrm{mg} / \mathrm{L}$ on the volcanic island of Fuerteventura Island, Spain [50], which potentially resulted from the relatively high $\mathrm{CO}_{2}$ partial pressure in the soil gas after the water-rock reactions. During this process, cations and balancing bicarbonate ions are released into the water and formed new aluminosilicates, such as kaolinite and 

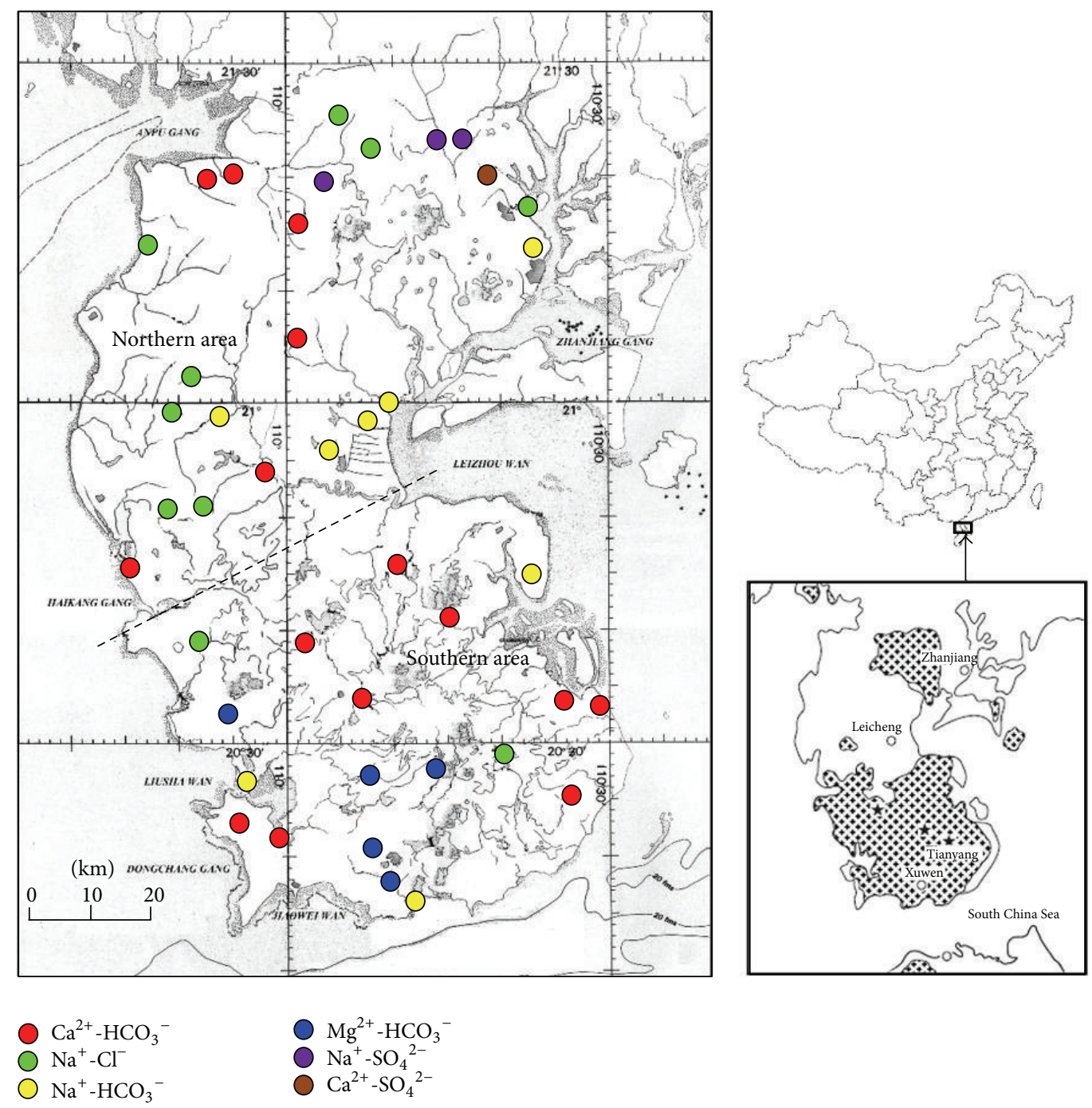
$\mathrm{Mg}^{2+}-\mathrm{HCO}_{3}$
$\mathrm{Na}^{+}-\mathrm{SO}_{4}{ }^{2-}$

(a)

(b)

FIGURE 7: Distribution of groundwater chemistry types.

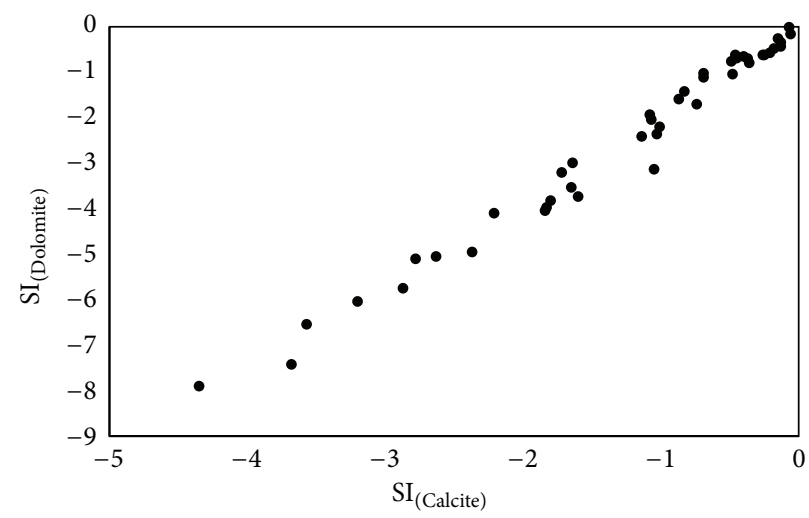

FIGURE 8: Saturation index (SI) of surface water and groundwater with respect to calcite and dolomite. 
smectite. In addition, a negative saturation index $(\mathrm{SI}<0)$ indicates undersaturation conditions and the dissolution of mineral phases (Figure 8 ). This value could correspond with the characteristics of water from a formation with insufficient mineral contents or short residence times [51]. The undersaturation of carbonates suggests that soluble carbonates mineral phases were absent in the host aquifer and that the dissolution of $\mathrm{CO}_{2}$ potentially contributed carbonates to the groundwater ((2) and (3)).

To understand regional hydrologic processes, statistical analyses of the correlations between certain pairs of parameters are shown in Figure 9. The $\mathrm{Ca}^{2+}$ and $\mathrm{Na}^{+}$concentrations were strongly correlated with the $\mathrm{HCO}_{3}{ }^{-}$concentration in the groundwater $\left(\mathrm{Ca}^{2+}=0.13 \times \mathrm{HCO}_{3}{ }^{-}+4.26, R^{2}=0.73\right.$; $\left.\mathrm{Na}^{+}=0.16 \times \mathrm{HCO}_{3}{ }^{-}-0.72, R^{2}=0.75\right)$, whereas the $\mathrm{Mg}^{2+}$ and $\mathrm{HCO}_{3}{ }^{-}$groundwater concentrations were weakly correlated $\left(\mathrm{Mg}^{2+}=0.05 \times \mathrm{HCO}_{3}{ }^{-}+2.76, \mathrm{R}^{2}=0.52\right)$. Additionally, the $\mathrm{Na}^{+}+\mathrm{Ca}^{2+}+\mathrm{Mg}^{2+}$ and $\mathrm{HCO}_{3}{ }^{-}+\mathrm{Cl}^{-}$concentrations were strongly correlated with the ion concentrations in the groundwater $\left(\mathrm{HCO}_{3}{ }^{-}+\mathrm{Cl}^{-}=2.23 \times\left(\mathrm{Na}^{+}+\mathrm{Ca}^{2+}+\mathrm{Mg}^{2+}\right)\right.$ $\left.+16.81, \mathrm{R}^{2}=0.59\right)$. The $\mathrm{Ca}^{2+}$ and $\mathrm{Mg}^{2+}$ groundwater concentrations were strongly correlated $\left(\mathrm{Mg}^{2+}=0.42 \times \mathrm{Ca}^{2+}+\right.$ $\left.0.92, R^{2}=0.64\right)$, but a different relationship was found between the $\mathrm{Na}^{+}$and $\mathrm{Ca}^{2+}$ concentrations. The groundwater samples showed a clustering of data at low $\mathrm{Cl}^{-}$and $\mathrm{Na}^{+}$ concentrations, and the relationship between the $\mathrm{Cl}^{-}$and $\mathrm{Na}^{+}$ concentrations in all of the samples could be expressed as $\mathrm{Na}^{+}$ $=0.55 \times \mathrm{Cl}^{-}+9.67\left(R^{2}=0.69\right)$. The relationships between $\mathrm{Cl}^{-}$ and $\mathrm{Na}^{+}$could be expressed as $\mathrm{Na}^{+}=0.85 \mathrm{Cl}^{-}$(the $\mathrm{Cl}^{-}$and $\mathrm{Na}^{+}$concentrations are expressed in units of mol/L). Thus, the $\mathrm{Na}^{+} / \mathrm{Cl}^{-}$slope of 0.85 for the surface water and groundwater was the same as that of the seawater.

The variations of $\mathrm{Na}^{+}, \mathrm{Ca}^{2+}, \mathrm{Mg}^{2+}$, and $\mathrm{HCO}_{3}{ }^{-}$were derived from natural weathering reactions [52], which suggested that the same geochemical processes occurred in the rock weathering reactions that released $\mathrm{Na}^{+}, \mathrm{Ca}^{2+}, \mathrm{Mg}^{2+}$, and $\mathrm{HCO}_{3}{ }^{-}$into the groundwater along the flow path. This interpretation is consistent with the water-rock interaction equation for basaltic aquifers. The different relationships between $\mathrm{Mg}^{2+}$ versus $\mathrm{Cl}^{-}$and $\mathrm{Ca}^{2+}$ versus $\mathrm{Cl}^{-}$(Figure 9) indicated different sources for $\mathrm{Mg}^{2+}, \mathrm{Ca}^{2+}$, and $\mathrm{Cl}^{-}$. In areas close to the sea, sea salt is a major contributor to sodium and chloride deposition, and the molar $\mathrm{Na} / \mathrm{Cl}$ ratio in precipitation is typically equal to that of sea salt $(0.86$ molar values, [53]). However, calculation of the $\mathrm{Na} / \mathrm{Cl}$ ratio is useful in sites that are far from the sea, with a range between 0.5 and 1.5 (molar values) considered to be acceptable [54]. These results indicate that the surface water and groundwater were influenced by seawater in the study region. Therefore, we can conclude that storms and typhoons carry salinity from the sea [55] and recharge groundwater through rainfall. In conclusion, the groundwater chemistry was potentially dominated by rock weathering and seawater carried by the Asian monsoon.

\section{Conclusions}

Isotopic and hydrochemical analyses were used to investigate the sources and recharge mechanisms of the groundwater in the Leizhou Peninsula. Most of the surface water and groundwater is considered to be fresh water and contains low ion concentrations. Nonetheless, the amount and quality of groundwater were affected by human activity to some extent. The bedrock in the southern area is covered by volcanic topography; thus, the chemistry of the groundwater in this region is different than that in the northern area. The groundwater in the southern area is classified as $\mathrm{Ca}^{2+}-\mathrm{Mg}^{2+}$ $\mathrm{HCO}_{3}{ }^{-}$-type with similar ion compositions, which indicates rapid and frequent water-rock exchange in the region. The groundwater type in the northern area is complex and is classified as the $\mathrm{HCO}_{3}{ }^{-}+\mathrm{Ca}^{2+}+\mathrm{Mg}^{2+}$-type and $\mathrm{Na}^{+}+\mathrm{Cl}^{-}$type, which represent low rates or the absence of modern recharge.

The regression equations of $\delta \mathrm{D}$ and $\delta^{18} \mathrm{O}$ for the surface water and the groundwater are similar to those for precipitation, which indicated meteoric origins. The $\delta \mathrm{D}$ and $\delta^{18} \mathrm{O}$ levels in the groundwater in this region are within a narrow range and are lower than those for winter precipitation. Additionally, the $\mathrm{Na}^{+} / \mathrm{Cl}^{-}$ratio of the surface water and the groundwater samples is identical to that of seawater. This result confirms that only rainfall with significant precipitation can recharge the groundwater.

This study has several limitations. Although seasonal influences are important for groundwater chemistry, the chemical composition data considered in this study represent only the groundwater chemistry during the wet season. The chemical concentrations were likely lower during the wet season than during the dry season.

Groundwater is considered to flow from inland areas to the coast, and the geochemical processes that occur during rock weathering reactions release $\mathrm{Na}^{+}, \mathrm{Ca}^{2+}, \mathrm{Mg}^{2+}$, and $\mathrm{HCO}_{3}{ }^{-}$into the groundwater along the flow path. The $\mathrm{HCO}_{3}{ }^{-}$concentrations are correlated with the $\mathrm{Ca}^{2+}, \mathrm{Na}^{+}$, and $\mathrm{Mg}^{2+}$ concentrations in the groundwater, and the $\mathrm{Cl}^{-}$ and $\mathrm{Na}^{+}$concentrations are strongly correlated in all of the samples. A reasonable conclusion is that the groundwater chemistry is dominated by rock weathering and that the seawater was carried by the Asian monsoon. These two processes result in a good positive correlation between the $\mathrm{Na}^{+}+\mathrm{Ca}^{2+}+\mathrm{Mg}^{2+}$ and $\mathrm{HCO}_{3}{ }^{-}+\mathrm{Cl}^{-}$concentrations.

Several basaltic volcanic aquifers exist around the world. Because of their relatively rapid hydrolysis and high hydraulic conductivities, studies of basaltic aquifers are important. These results highlight the meteoric origins, rock-water interactions, and seawater carried by monsoons in groundwater flow processes and can be applied in the future to better manage basaltic volcanic aquifers.

\section{Conflict of Interests}

The authors declare no conflict of interests.

\section{Acknowledgments}

This study was supported in part by grants from the Beijing Natural Science Foundation (no. 8142031) and the Fundamental Research Funds for Beijing Jiaotong University 

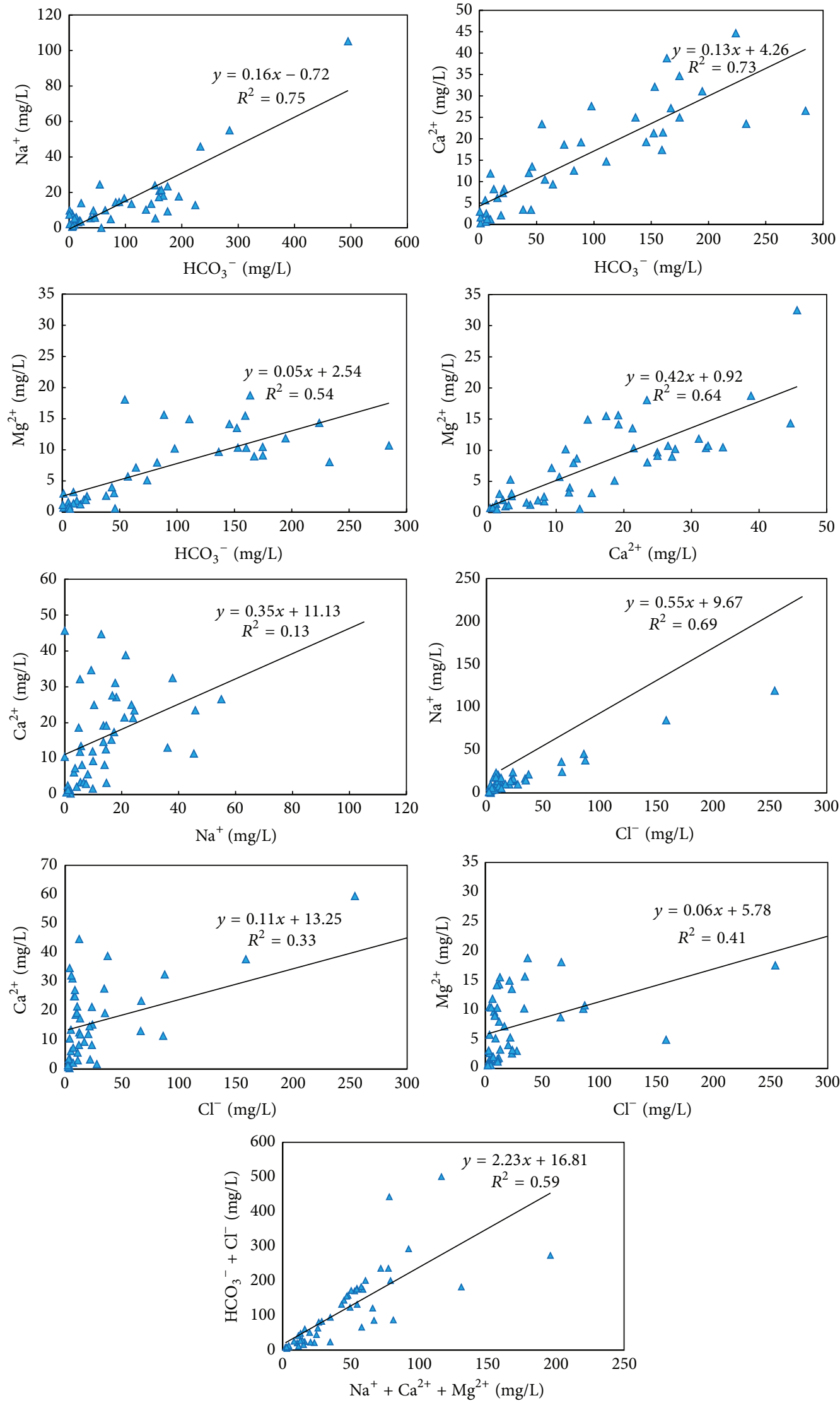

FIGURE 9: Correlations between certain pairs of parameters in the groundwater; solid lines indicate correlation curves. 
(no. C15RC00090). The authors thank the anonymous reviewers for their time and effort.

\section{References}

[1] J.-H. Yu, S. Y. O'Reilly, W. L. Griffin, X. S. Xu, M. Zhang, and X. M. Zhou, "The thermal state and composition of the lithospheric mantle beneath the Leizhou Peninsula, South China," Journal of Volcanology and Geothermal Research, vol. 122, no. 3-4, pp. 165-189, 2003.

[2] T. Pu, Y. He, T. Zhang, J. Wu, G. Zhu, and L. Chang, "Isotopic and geochemical evolution of ground and river waters in a karst dominated geological setting: a case study from Lijiang basin, South-Asia monsoon region," Applied Geochemistry, vol. 33, pp. 199-212, 2013.

[3] J. V. Cruz and C. S. Amaral, "Major ion chemistry of groundwater from perched-water bodies of the Azores (Portugal) volcanic archipelago," Applied Geochemistry, vol. 19, no. 3, pp. 445-459, 2004.

[4] S. T. Goldsmith, A. E. Carey, W. B. Lyons, and D. M. Hicks, "Geochemical fluxes and weathering of volcanic terrains on high standing islands: taranaki and Manawatu-Wanganui regions of New Zealand," Geochimica et Cosmochimica Acta, vol. 72, no. 9, pp. 2248-2267, 2008.

[5] Y. Han and Y. Huh, "A geochemical reconnaissance of the Duman (Tumen) River and the hot springs of Mt. Baekdu (Changbai): weathering of volcanic rocks in mid-latitude setting," Chemical Geology, vol. 264, no. 1-4, pp. 162-172, 2009.

[6] N. J. Pawar, J. B. Pawar, S. Kumar, and A. Supekar, "Geochemical eccentricity of ground water allied to weathering of basalts from the deccan volcanic province, India: insinuation on $\mathrm{CO}_{2}$ consumption," Aquatic Geochemistry, vol. 14, no. 1, pp. 41-71, 2008.

[7] E. Dafny, A. Burg, and H. Gvirtzman, "Deduction of groundwater flow regime in a basaltic aquifer using geochemical and isotopic data: the Golan Heights, Israel case study," Journal of Hydrology, vol. 330, no. 3-4, pp. 506-524, 2006.

[8] F. D. Li, G. Y. Pan, C. Y. Tang, Q. Y. Zhang, and J. J. Yu, "Recharge source and hydrogeochemical evolution of shallow groundwater in a complex alluvial fan system, southwest of North China Plain," Environmental Geology, vol. 55, no. 5, pp. 1109-1122, 2008.

[9] A. M. Marfia, R. V. Krishnamurthy, E. A. Atekwana, and W. F. Panton, "Isotopic and geochemical evolution of ground and surface waters in a karst dominated geological setting: a case study from Belize, Central America," Applied Geochemistry, vol. 19, no. 6, pp. 937-946, 2004.

[10] B. D. Smerdon, D. M. Allen, S. E. Grasby, and M. A. Berg, "An approach for predicting groundwater recharge in mountainous watersheds," Journal of Hydrology, vol. 365, no. 3-4, pp. 156-172, 2009.

[11] C. Federico, A. Aiuppa, R. Favara, S. Gurrieri, and M. Valenza, "Geochemical monitoring of groundwaters (1998-2001) at Vesuvius volcano (Italy)," Journal of Volcanology and Geothermal Research, vol. 133, no. 1-4, pp. 81-104, 2004.

[12] S. Caliro, G. Chiodini, R. Avino, C. Cardellini, and F. Frondini, "Volcanic degassing at Somma-Vesuvio (Italy) inferred by chemical and isotopic signatures of groundwater," Applied Geochemistry, vol. 20, no. 6, pp. 1060-1076, 2005.

[13] S. K. Gupta, R. D. Deshpande, S. K. Bhattacharya, and R. A. Jani, "Groundwater $\delta^{18} \mathrm{O}$ and $\delta \mathrm{D}$ from central Indian Peninsula: influence of the Arabian Sea and the Bay of Bengal branches of the summer monsoon," Journal of Hydrology, vol. 303, no. 1-4, pp. 38-55, 2005.

[14] G. La Ruffa, C. Panichi, T. Kavouridis, V. Liberopoulou, J. Leontiadis, and A. Caprai, "Isotope and chemical assessment of geothermal potential of Kos Island, Greece," Geothermics, vol. 28, no. 2, pp. 205-217, 1999.

[15] E. Dotsika, I. Leontiadis, D. Poutoukis, R. Cioni, and B. Raco, "Fluid geochemistry of the Chios geothermal area, Chios Island, Greece," Journal of Volcanology and Geothermal Research, vol. 154, no. 3-4, pp. 237-250, 2006.

[16] H. Xu, Z. Hou, Z. An, X. Liu, and J. Dong, "Major ion chemistry of waters in Lake Qinghai catchments, NE QinghaiTibet plateau, China," Quaternary International, vol. 212, no. 1, pp. 35-43, 2010.

[17] W. Zhong, J. Y. Cao, J. B. Xue et al., "Carbon isotope evidence of last glacial climate variations in the tropical NW Leizhou Peninsula, South China," Boreas, vol. 41, no. 1, pp. 102-112, 2012.

[18] Z. Xun, Y. Xia, L. Juan, Y. Jinmei, and D. Wenyu, "Evolution of the groundwater environment under a long-term exploitation in the coastal area near Zhanjiang, China," Environmental Geology, vol. 51, no. 5, pp. 847-856, 2007.

[19] J.-H. Won, J.-Y. Lee, J.-W. Kim, and G.-W. Koh, "Groundwater occurrence on Jeju Island, Korea," Hydrogeology Journal, vol. 14, no. 4, pp. 532-547, 2006.

[20] S. Kebede, Y. Travi, T. Alemayehu, and T. Ayenew, "Groundwater recharge, circulation and geochemical evolution in the source region of the Blue Nile River, Ethiopia," Applied Geochemistry, vol. 20, no. 9, pp. 1658-1676, 2005.

[21] H. H. Wen, Study on circulation pattern and numerical modeling of groundwater flow in Leizhou Peninsula [Ph.D. thesis], China University of Geosciences, Beijing, China, 2013, (Chinese).

[22] C. Y. Tang, J. H. Chen, A. Kondo, and Y. T. Lu, "Characteristics soil water movements and water table at the Leizhou Peninsula, Guangzhou Province, China," Advances in Geosciences, vol. 16, pp. 219-227, 2006.

[23] S. Schofield and J. Jankowski, "Hydrochemistry and isotopic composition of $\mathrm{Na}-\mathrm{HCO}_{3}$-rich groundwaters from the Ballimore region, central New South Wales, Australia," Chemical Geology, vol. 211, no. 1-2, pp. 111-134, 2004.

[24] F. D. Li, Q. Y. Zhang, C. Y. Tang, K. Fukumoto, and H. Ota, "Denitrifying bacteria and hydrogeochemistry in a natural wetland adjacent to farmlands in Chiba, Japan," Hydrological Processes, vol. 25, no. 14, pp. 2237-2245, 2011.

[25] M. L. Coleman, T. J. Shepherd, J. J. Durham, J. E. Rouse, and G. R. Moore, "Reduction of water with zinc for hydrogen isotope analysis," Analytical Chemistry, vol. 54, no. 6, pp. 993-995, 1982.

[26] K. Z. Li, J. Q. Yin, L. G. Huang, J. L. Zhang, S. M. Lian, and C. M. Liu, "Distribution and abundance of thaliaceans in the northwest continental shelf of South China Sea, with response to environmental factors driven by monsoon," Continental Shelf Research, vol. 31, no. 9, pp. 979-989, 2011.

[27] R. J. Gibbs, "Mechanisms controlling world water chemistry," Science, vol. 170, no. 3962, pp. 1088-1090, 1970.

[28] E. Bozau, S. Häußler, and W. van Berk, "Hydrogeochemical modelling of corrosion effects and barite scaling in deep geothermal wells of the North German Basin using PHREEQC and PHAST," Geothermics, vol. 53, pp. 540-547, 2015.

[29] C.-W. Liu, C.-C. Lai, Y.-Y. Chen, and K.-L. Lu, "Hydrogeochemical and mineralogical investigations of arsenic- and humic substance-enriched aquifers," Journal of Hydrology, vol. 498, pp. 59-75, 2013. 
[30] J. Peña, B. Buil, A. Garralón et al., "The vaterite saturation index can be used as a proxy of the S\&DSI in sea water desalination by reverse osmosis process," Desalination, vol. 254, no. 1-3, pp. 75-79, 2010.

[31] G. Jeelani, U. S. Kumar, and B. Kumar, "Variation of $\delta^{18} \mathrm{O}$ and $\delta \mathrm{D}$ in precipitation and stream waters across the Kashmir Himalaya (India) to distinguish and estimate the seasonal sources of stream flow," Journal of Hydrology, vol. 481, pp. 157$165,2013$.

[32] G. Jeelani, N. A. Bhat, and K. Shivanna, "Use of $\delta^{18} \mathrm{O}$ tracer to identify stream and spring origins of a mountainous catchment: a case study from Liddar watershed, Western Himalaya, India," Journal of Hydrology, vol. 393, no. 3-4, pp. 257-264, 2010.

[33] L. Yin, G. Hou, X. S. Su et al., "Isotopes $\left(\delta D\right.$ and $\left.\delta^{18} O\right)$ in precipitation, groundwater and surface water in the Ordos Plateau, China: implications with respect to groundwater recharge and circulation," Hydrogeology Journal, vol. 19, no. 2, pp. 429-443, 2011.

[34] K. Froehlich, J. J. Gibson, and P. K. Aggarwal, "Deuterium excess in precipitation and its climatological significance," in Study of Environmental Change Using Isotope Techniques, pp. 54-66, IAEA, Vienna, Austria, 2002.

[35] P. Wang, J. J. Yu, Y. C. Zhang, and C. M. Liu, "Groundwater recharge and hydrogeochemical evolution in the Ejina Basin, northwest China," Journal of Hydrology, vol. 476, pp. 72-86, 2013.

[36] L. F. Xu, Y. Lin, H. J. Gang, H. N. Yang, and B. Xu, “Temporal and spatial variation of NPS pollutants in surface water of Leizhou Peninsula," Ecology and Environment, vol. 14, no. 6, pp. 830-834, 2005 (Chinese).

[37] I. Farid, R. Trabelsi, K. Zouari, and R. Beji, "Geochemical and isotopic study of surface and groundwaters in Ain Bou Mourra basin, central Tunisia," Quaternary International, vol. 303, pp. 210-227, 2013.

[38] Y. Wang and J. J. Jiao, "Origin of groundwater salinity and hydrogeochemical processes in the confined quaternary aquifer of the Pearl River Delta, China," Journal of Hydrology, vol. 438439, no. 7, pp. 112-124, 2012.

[39] S. Maassen, D. Balla, and R. Dannowski, "Long-term behavior of groundwater chemistry in a periodically rewetted fen area covered with macrophytes," Journal of Environmental Management, vol. 150, pp. 412-419, 2015.

[40] K. P. Singh, S. Gupta, and D. Mohan, "Evaluating influences of seasonal variations and anthropogenic activities on alluvial groundwater hydrochemistry using ensemble learning approaches," Journal of Hydrology, vol. 511, no. 4, pp. 254-266, 2014.

[41] C. Y. Lin, M. H. Abdullah, S. M. Praveena, A. H. B. Yahaya, and B. Musta, "Delineation of temporal variability and governing factors influencing the spatial variability of shallow groundwater chemistry in a tropical sedimentary island," Journal of Hydrology, vol. 432-433, pp. 26-42, 2012.

[42] R. K. Dhar, Y. Zheng, M. Stute et al., "Temporal variability of groundwater chemistry in shallow and deep aquifers of Araihazar, Bangladesh," Journal of Contaminant Hydrology, vol. 99, no. 1-4, pp. 97-111, 2008.

[43] X.-L. Huang, Y.-G. Xu, C.-H. Lo, R.-C. Wang, and C.-Y. Lin, "Exsolution lamellae in a clinopyroxene megacryst aggregate from Cenozoic basalt, Leizhou Peninsula, South China: petrography and chemical evolution," Contributions to Mineralogy and Petrology, vol. 154, no. 6, pp. 691-705, 2007.
[44] E. Lacroix, A. Brovelli, C. Holliger, and D. A. Barry, "Control of groundwater $\mathrm{pH}$ during bioremediation: improvement and validation of a geochemical model to assess the buffering potential of ground silicate minerals," Journal of Contaminant Hydrology, vol. 160, pp. 21-29, 2014.

[45] K.-S. Ho, J.-C. Chen, and W.-S. Juang, "Geochronology and geochemistry of late Cenozoic basalts from the Leiqiong area, southern China," Journal of Asian Earth Sciences, vol. 18, no. 3, pp. 307-324, 2000.

[46] H. T. Schaef, B. P. McGrail, and A. T. Owen, "Basalt- $\mathrm{CO}_{2}-\mathrm{H}_{2} \mathrm{O}$ interactions and variability in carbonate mineralization rates," Energy Procedia, vol. 1, pp. 4899-4906, 2009.

[47] S. Peuble, M. Godard, L. Luquot, M. Andreani, I. Martinez, and P. Gouze, " $\mathrm{CO}_{2}$ geological storage in olivine rich basaltic aquifers: new insights from reactive-percolation experiments," Applied Geochemistry, vol. 52, pp. 174-190, 2015.

[48] R. A. Berner and D. J. Beerling, "Volcanic degassing necessary to produce a $\mathrm{CaCO}_{3}$ undersaturated ocean at the Triassic-Jurassic boundary," Palaeogeography, Palaeoclimatology, Palaeoecology, vol. 244, no. 1-4, pp. 368-373, 2007.

[49] G. Bertrand, H. Celle-Jeanton, F. Huneau, S. Loock, and C. Renac, "Identification of different groundwater flowpaths within volcanic aquifers using natural tracers for the evaluation of the influence of lava flows morphology (Argnat basin, Chaîne des Puys, France)," Journal of Hydrology, vol. 391, no. 3-4, pp. 223-234, 2010.

[50] C. Herrera and E. Custodio, "Groundwater flow in a relatively old oceanic volcanic island: the Betancuria area, Fuerteventura Island, Canary Islands, Spain," Science of the Total Environment, vol. 496, pp. 531-550, 2014.

[51] A. K. Tiwari and A. K. Singh, "Hydrogeochemical investigation and groundwater quality assessment of Pratapgarh district, Uttar Pradesh," Journal of the Geological Society of India, vol. 83, no. 3, pp. 329-343, 2014.

[52] B. Zhang, X. Song, Y. Zhang et al., "Hydrochemical characteristics and water quality assessment of surface water and groundwater in Songnen plain, Northeast China," Water Research, vol. 46, no. 8, pp. 2737-2748, 2012.

[53] W. C. Keene, A. A. P. Pszenny, J. N. Galloway, and M. E. Hawley, "Sea-salt corrections and interpretation of constituent ratios in marine precipitation," Journal of Geophysical Research: Atmospheres, vol. 91, pp. 6647-6658, 1986.

[54] A. Thimonier, M. Schmitt, P. Waldner, and P. Schleppi, "Seasonality of the $\mathrm{Na} / \mathrm{Cl}$ ratio in precipitation and implications of canopy leaching in validating chemical analyses of throughfall samples," Atmospheric Environment, vol. 42, no. 40, pp. $9106-$ 9117, 2008.

[55] K. Z. Li, J. Q. Yin, L. M. Huang, S. M. Lian, J. L. Zhang, and C. G. Liu, "Monsoon-forced distribution and assemblages of appendicularians in the northwestern coastal waters of South China Sea," Estuarine, Coastal and Shelf Science, vol. 89, no. 2, pp. 145-153, 2010. 

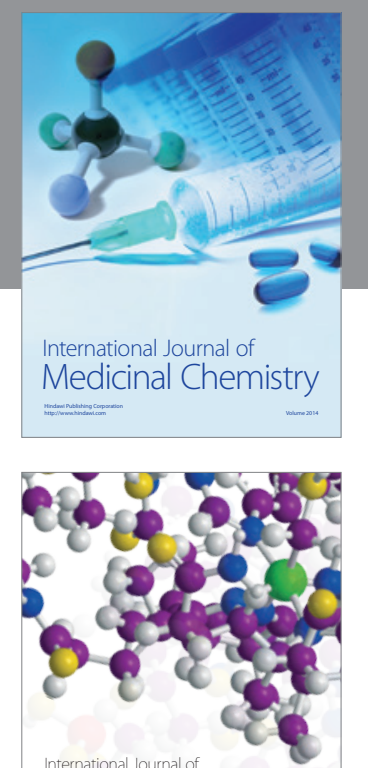

\section{Carbohydrate} Chemistry

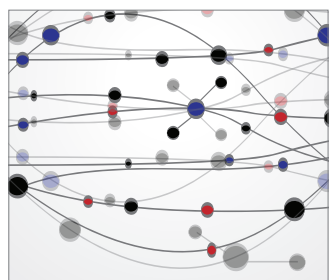

The Scientific World Journal
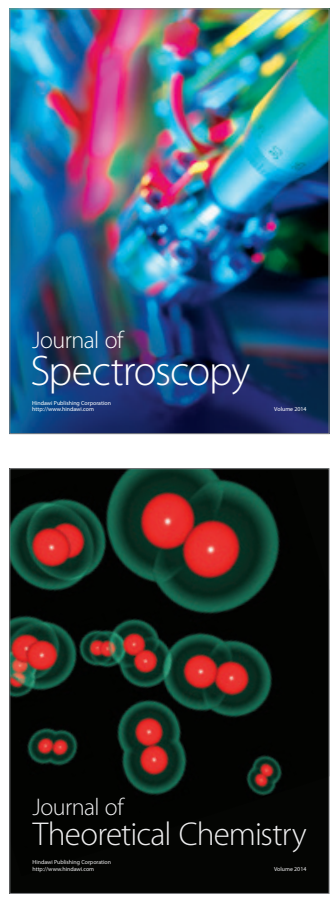
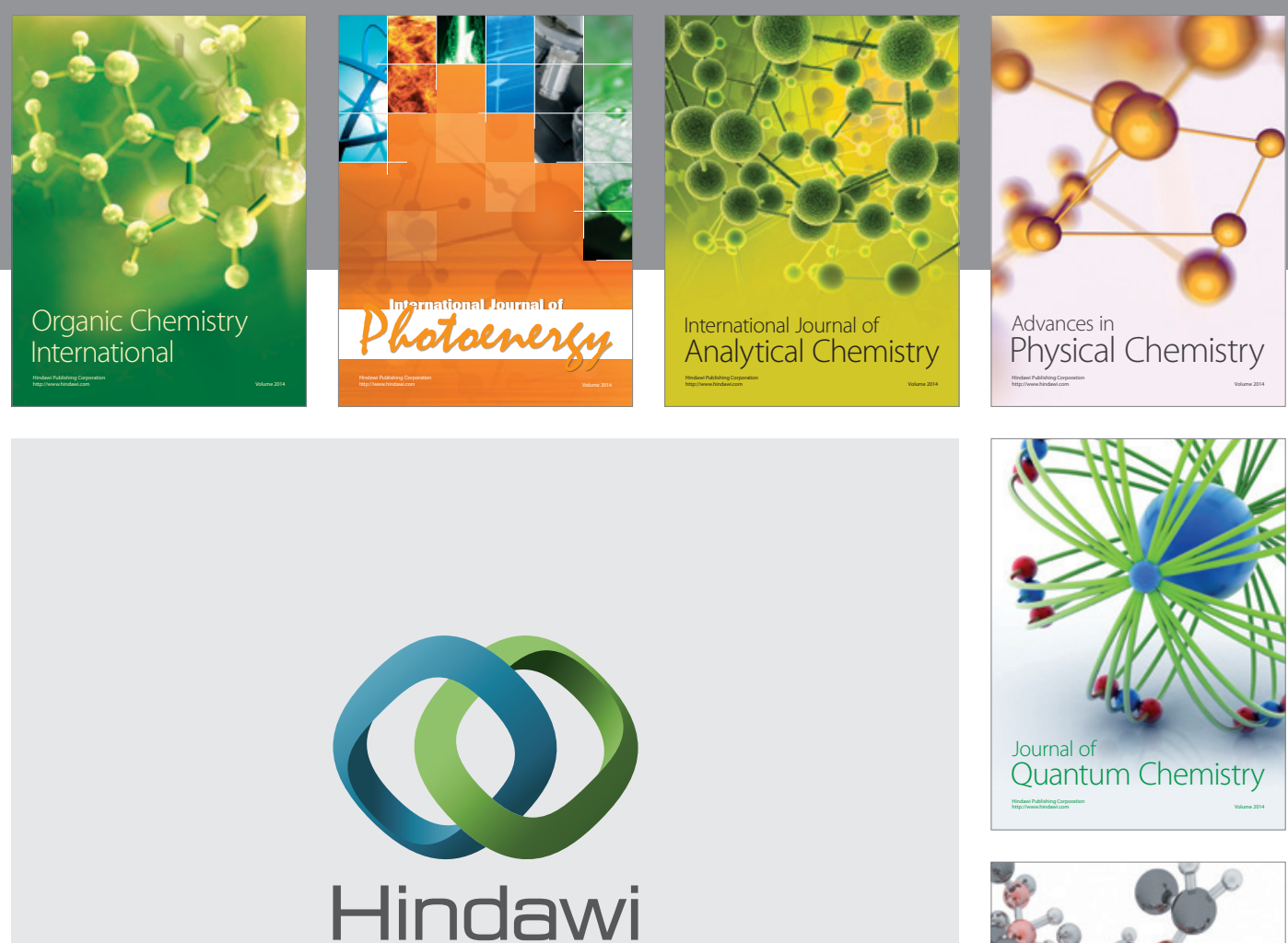

Submit your manuscripts at

http://www.hindawi.com

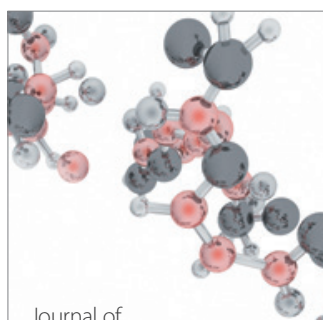

Analytical Methods

in Chemistry

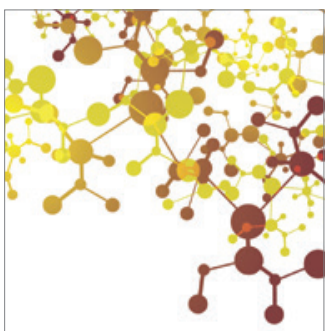

Journal of

Applied Chemistry

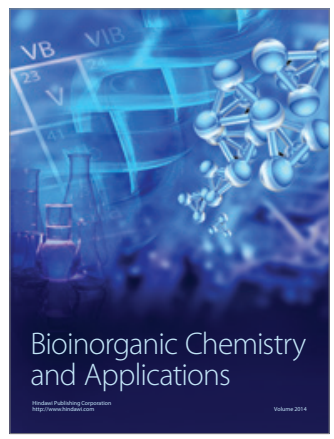

Inorganic Chemistry
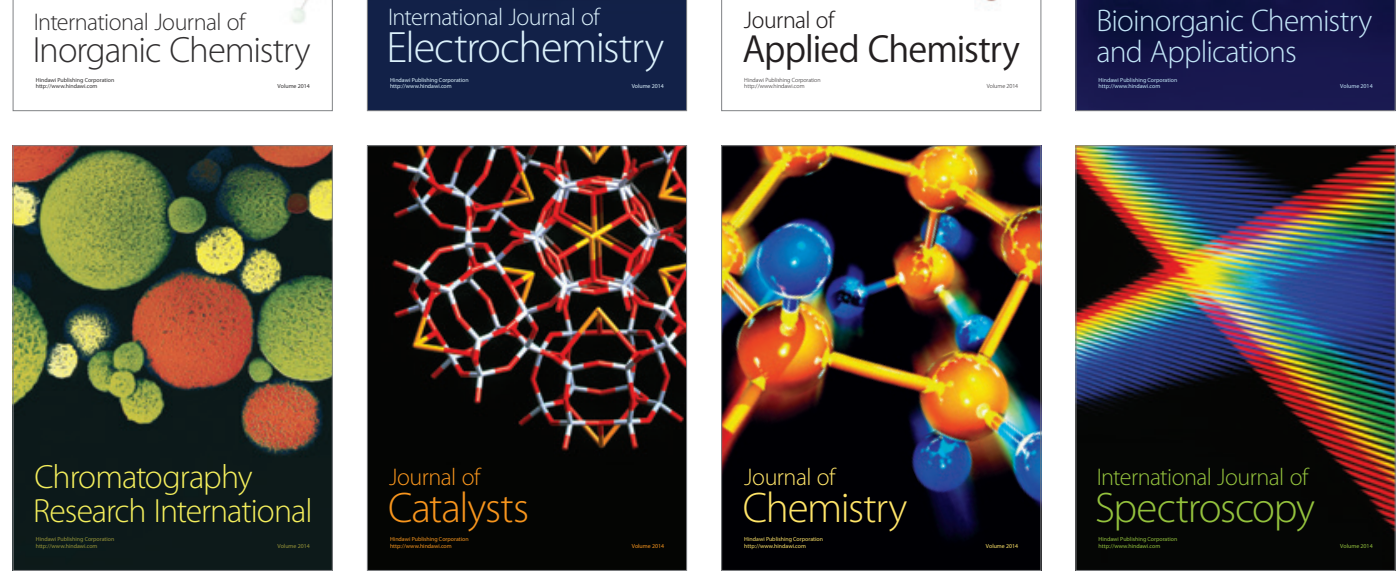